\title{
sciendo
}

Transport and Telecommunication, 2021, volume 22, no. 2, 183-195

Transport and Telecommunication Institute, Lomonosova 1, Riga, LV-1019, Latvia DOI 10.2478/ttj-2021-0014

\section{IMPACT OF REGIONAL CLIMATE CHANGE ON THE INFRASTRUCTURE AND OPERABILITY OF RAILWAY TRANSPORT}

\author{
Evgeniia A. Kostianaia ${ }^{1}$, Andrey G. Kostianoy ${ }^{1,2}$, Mikhail A. Scheglov ${ }^{3}$, \\ Aleksey I. Karelov ${ }^{3}$, Alexander S. Vasileisky ${ }^{3}$ \\ ${ }^{I}$ Shirshov Institute of Oceanology, Russian Academy of Sciences \\ Moscow, Russia, 36, Nahimovskiy Prospekt \\ evgeniia.kostianaia@ocean.ru,kostianoy@gmail.com \\ ${ }^{2}$ S.Yu. Witte Moscow University \\ Moscow, Russia, 12, Build. 1, Second Kozhukhovsky Pr. \\ ${ }^{3}$ Research and Design Institute for Information Technology, Signalling and Telecommunications on \\ Railway Transport, Russian Railways subsidiary, \\ Moscow, Russia, 27, Build. 1, Nizhegorodskaya Str. \\ m.scheglov@vniias.ru,a.karelov@vniias.ru,a.vasileisky@vniias.ru
}

\begin{abstract}
This article considers various aspects of the impact of climate change on the railway infrastructure and operations. A brief international overview and the importance of this issue for Russia are given. Temperature effects, permafrost thawing, strong winds, floods and sea level rise, long-term effects, and adaptation measures are discussed. In conclusion, the authors give several recommendations on further research in this area, and highlight that special attention should be given to the areas in the Russian Federation which already face or might soon experience damage from storm events or flooding and sea level rise, namely Kaliningrad Region on the Baltic Sea, the area between Tuapse and Adler in Krasnodar Region on the Black Sea, and on Sakhalin Island from the side of the Sea of Japan.
\end{abstract}

Keywords: Regional climate change, extreme weather events, rail transport, railways infrastructure, buckling of tracks, flooding of tracks

\section{Introduction}

Climate change is now widely recognized as a serious issue affecting not only the environment, but also the society and economies in the world. A huge number of scientific articles and reports have been published not only with the aim to analyse past and present trends and provide climate predictions, but also to evaluate the impacts of climate change on human health, food production, marine environment, and many other fields. Some of such studies focus on the impact of climate change on rail infrastructure, which is a crucial part of any country's transportation network. According to the Fifth Assessment Report of the Intergovernmental Panel on Climate Change (2014), climate warming is unequivocal. The temperature of the surface is projected to increase in the $21^{\text {st }}$ century, with heat waves to be very likely to happen more frequently and with more intense and regular extreme precipitation events across many parts of the world. The global mean sea level is also expected to rise. It is evident that such changing climate may have a significant adverse impact on the railway infrastructure, as such changes may lead to, for example, rail buckling, rail flooding, expansion of swing bridges, overheating of electrical equipment and its damage, bridge scour, failure of earthworks, ground settlement, pavement deterioration, damage to sea walls, coastal erosion of tracks and earthworks, and an increased number of railway accidents in general (Rail Safety and Standards Board, 2016; Li \& Kaewunruen, 2019). Therefore, it is crucial to gather substantial knowledge on what climate change impacts the railway transport may see in the near future, and what adaptation measures they should have ready in order to reduce potential financial losses from such impacts as well as to minimize any chance of accidents.

The elements of railway infrastructure are subject to various kinds of impacts both directly from the movement of trains and the environment. Over the past 100 years, the traffic intensity has changed, and at the same time in many zones the climate has changed significantly and seismic activity has 
increased. All this has led to intensification of dangerous processes (landslides, mudflows, avalanches, floods) and is the reason for the rapid obsolescence of existing engineering, geological, landscape and climate information embedded in the projects of railway infrastructure.

Railway engineering should take into account climate change impacts in order to improve the efficiency of railway infrastructure under extreme weather conditions. There have already been instances of severe weather events, which led to human deaths and considerable financial losses. For example, in 1998, severe flooding in China led to more than 4,000 deaths and 15 million homeless, many destroyed infrastructures and overall economic loss of \$24 billion (Li \& Kaewunruen, 2019). The two-day heatwave in the UK between June 30 and July 1, 2015, resulted in more than 220,000 delay-minutes, and an estimated $£ 16$ million loss to the national economy (Ferranti et al., 2018). Sometimes, it is not even possible to get an exact estimate of the economic losses, as there are also indirect losses due to disruption of railway operations. For example, Network Rail in the UK estimated that the cost of repairing the track at Dawlish, which was destroyed by storms on 4 and 14 February 2014 and was closed for 8 weeks, was about $£ 35$ million (HoCTC, 2015). However, there was also a wider economic impact of this rail disruption on tourism, fishing, as well as other industries in Devon, which was assessed to range between $£ 60$ million and $£ 1.2$ billion. About 340 southwest businesses expressed that they were having difficulties following the closure of the rail link to London and that they had minimum losses between $£ 100$ and $£ 1,000$ per day when the line was closed (DMF, 2015).

Nemry and Demirel (2012) in a comprehensive report "Impacts of Climate Change on Transport: A focus on road and rail transport infrastructures" provided an overview of climate change impacts on the transport system. Increased summer temperatures could result in rail track buckling and thermal extension of bridges. Increased winter temperatures could, on the contrary, reduce constraints for rail maintenance and change construction seasons overall. Increased precipitation could lead to flooding of transport infrastructures, bridge scour, more frequent slushflow avalanches, landslides and related risks. Increased and more frequent extreme winds could cause damage to railway infrastructure. Sea level rise and sea storm surges are thought to lead to regular and permanent inundation of railway areas, bridge scour and corrosion. Permafrost degradation and thawing are expected to cause rail failures.

The impact of climate change on railway transport in different regions is expected to vary due to the fact that across the world the climate will change in different ways (Koetse \& Rietveld, 2009). For example, according to the report "Climate Risks and Adaptation Practices for the Canadian Transportation Sector 2016" (Palko \& Lemmen, 2017), in Canada extreme precipitation and coastal storm surges may cause washouts, whereas temperature extremes and permafrost degradation can entail slower train speeds and also cause derailments. However, at the same time, winters are projected to get warmer throughout the whole country, which may reduce track and mechanical issues induced by extreme cold.

For the Russian Federation, there are these three main documents containing the necessary data on climate change in the country:

(1) The second assessment report of Roshydromet on climate changes and their consequences on the territory of the Russian Federation (Second Assessment..., 2014);

(2) "Atlas of natural and technological hazards and risks of emergency situations. Russian Federation" (Atlas..., 2010);

(3) Fifth Assessment Report of the Intergovernmental Panel on Climate Change (IPCC, 2014).

However, these documents do not contain detailed information on the impacts of climate change on sections of the railway network in the Russian Federation. Climate warming in Russia, which occurs almost 2 times faster than the global average (Second Assessment..., 2014), is accompanied by accelerated degradation of permafrost, an increase in the level of marginal seas, a shift in the trajectories of air masses, an increase in the intensity of rain showers, snowfalls and blizzards, more frequent floods, landslides, mudflows, fires and other dangerous natural phenomena and processes that may pose a threat to the infrastructure and operability of railway transport in the Russian Federation.

The purpose of this article is to provide an overview of the climate change impacts on the railway infrastructure internationally, including some examples of adaptation measures. This paper will focus on such climate change and extreme weather impacts as temperature changes, permafrost, increased winds, flooding and sea level rise. The paper also discusses several cases of such effects in the Russian Federation and provides recommendations for further research in this area in the Russian Federation.

\section{Temperature effects}

One of the most tangible effects of climate change is temperature increase, which can have a direct impact on the railway infrastructure. In the United Kingdom, according to a report by Rail Safety and 
Standards Board (2003), hot dry summers are expected to cause increased buckling of train track, desiccation of track earthworks, more need for installation of air conditioning systems. "Rail track buckling" is a term describing large lateral misalignments in continuous welded rail track, or CWR (Figure 1). CWR has been widely used across many countries in the world and is subject to the impact of high and cold temperatures (dilatation or contraction, correspondingly) (Nemry and Demirel, 2012). Furthermore, hot dry summers in the UK might also cause problems with vegetation due to prolongation of the growing season, and could necessitate amended actions for the removal of leaf deposit (Baker et al., 2009). An important factor contributing to track deformations is the load on the rails, and therefore, with increasing temperature, it is advisable to introduce restrictions on the speed of trains. For example, in the United Kingdom at an air temperature of $36^{\circ} \mathrm{C}$, blanket speed restrictions are required regardless of the rail temperature. The temperature at which a rail may buckle also depends on the condition of the rail itself (Dobney et al., 2009).

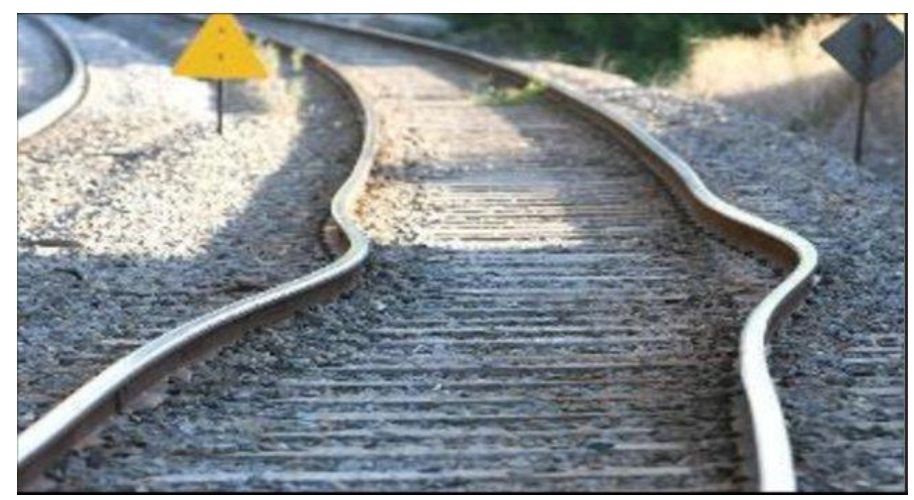

Figure 1. Rail track buckling in Australia (Mandal, Lees, 2016)

Stability of the assembled rails and sleepers in extremely high temperatures is also a serious problem under climate warming. The temperature of fastening welded rail strings is one of the most important technical characteristics of the railway structure, affecting the stability of the track grid, ability to carry out track works, the degree of opening of gaps at the joints; fatigue strength and other effects. According to the regulatory document issued by the Russian Ministry of Railways (2000), it was recommended that welded rail strings should be fixed at a temperature of $35 \pm 5^{\circ} \mathrm{C}$ in the south of Russia, at $30 \pm 5^{\circ} \mathrm{C}$ in the central part of the country, and at $25 \pm 5^{\circ} \mathrm{C}$ in Eastern Siberia and some other territories. However, due to an already happening climate warming in the Russian Federation, these parameters were increased in the regulatory document in 2012 by $5-10^{\circ} \mathrm{C}$ depending on the territory (Russian Railways, 2012).

Nonetheless, cold temperatures are also problematic for the railway infrastructure. According to the studies of Grigoriev and Lepov in the Republic of Sakha in Russia (also known as Yakutia, a region in the Far East with a long winter and short summer period) (Grigoriev and Lepov, 2012, 2014), low temperatures lead to deterioration of the mechanical properties of the material of the wheel bandage, embrittlement of the material due to loss of plasticity. Accordingly, colder winter periods can lead to higher costs for the maintenance of rolling stock. Extreme cold temperatures may result in breaking of tracks. Ice formation on tracks can be a cause for slippery conditions, which may lead to derailments. Thus, trains will need to decrease the speed and start to break earlier. Another problem with ice is that it can block switches. In order to fix this, switches are supplied with electric heaters. Overall, low temperature can lead to damage to cables, loss of electricity and frost, which may induce overheating of safety devices, material damage to railway equipment, sagging of supply cables and tensional failure, as well as damage to rail track. In terms of railway operations, this may mean delayed, stopped, or cancelled railway services, accidents and general change in quality of railway services (Oslakovic et al., 2013).

\section{Permafrost}

A significant part of the railway infrastructure of the Eastern territory in the Russian Federation is located in the zone of permafrost (Figure 2). Extremely difficult engineering and geological conditions are exacerbated by the natural climatic and technological degradation of permafrost at the base of the track. In addition, railway infrastructure for a long distance is constantly or periodically affected by the following natural processes and phenomena: coastal abrasion, mudflows, floods, erosion, landslides and 
floats, karst dips, suffusion subsidence, ice, thermokarst, thermoerosion and solifluction, explosive deformations, frosty heaving, avalanches, etc (World experience..., 2017).

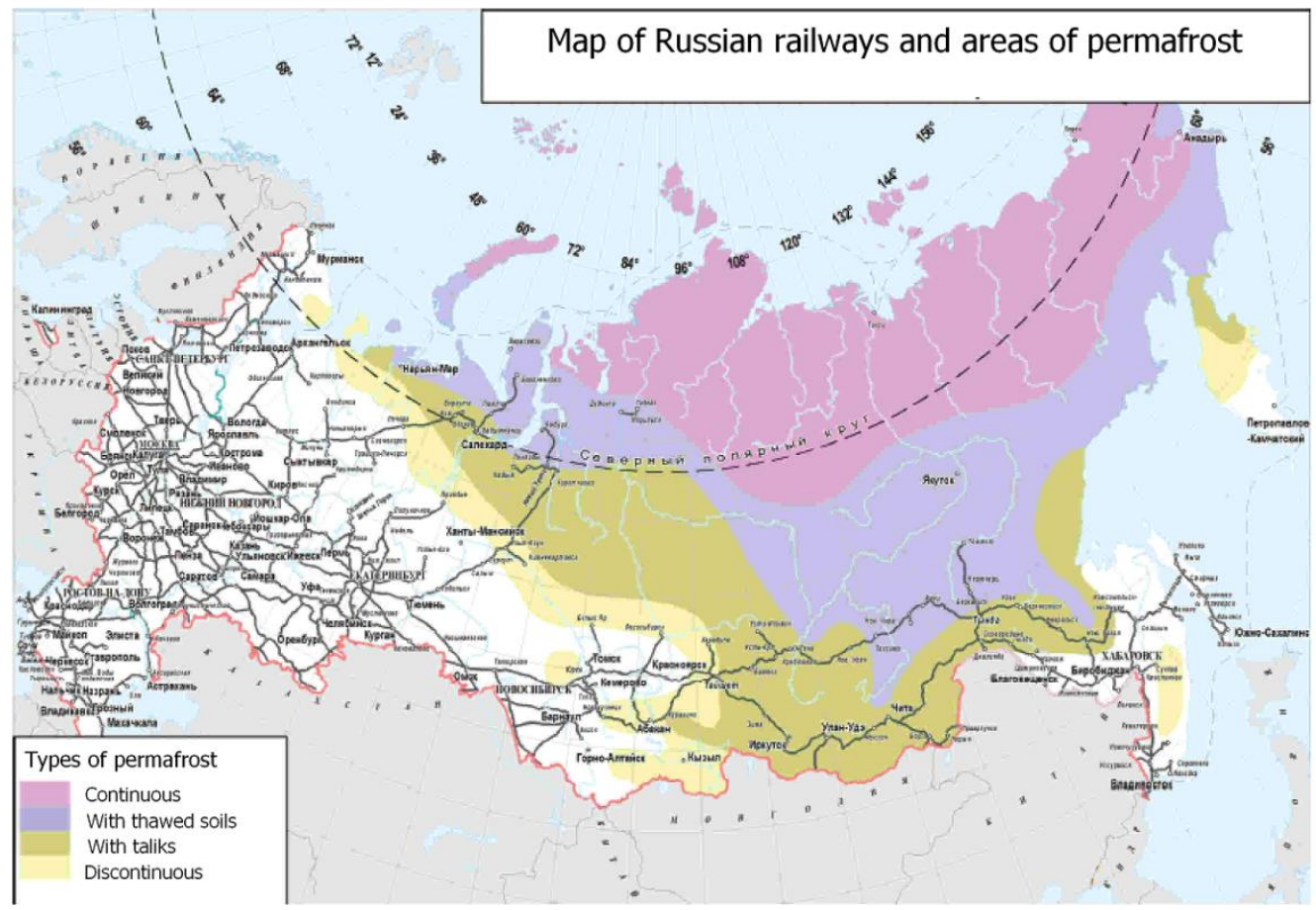

Figure 2. Map of Russian railways and the areas of permafrost. Adapted from (World experience..., 2017)

Areas located in the permafrost zone are characterized by increased deformability caused by cryogenic processes in the foundation soils, primarily, by the settlement of layers on a thawing base (at a speed of up to 10-20 cm per year). The causes of deformations in the first decades after the construction of infrastructure facilities on frozen soils are associated with the degradation of permafrost at the foundation caused by violation of the natural conditions of heat transfer between the atmosphere and the soil mass, thawing and compaction sediments. Subsequently, plastic deformations of flooded melt soils, with their extrusion to the sides under the layer weight and dynamic train load, become the predominant deformability factor. Watering, in turn, is associated with the degradation of frozen rocks, disruption of the drain system, irrational placement of discharge and drainage structures (World experience..., 2017).

An additional contribution to the degradation of permafrost rocks at the base of the track and artificial structures is made by changes in climatic conditions, which is observed in recent decades in the area of the railway infrastructure in the east of Russia. Such changes comprise a gradual increase in average annual temperatures (up to 0.5 degrees per decade), as well as regional climatic changes associated with anthropogenic impacts (primarily creation of water reservoirs). Over the course of the 20th century, there was an increase in the temperature of the upper layers of permafrost soils and an increase in the depth of seasonal thawing. Moreover, these processes have accelerated in the last four decades. The average air temperature in the $20^{\text {th }}$ century globally increased by 0.6 degrees, while in the area of permafrost in Russia it reached 5 degrees (Second Assessment..., 2014).

In the first 80 years of the 20th century, the temperature of the upper horizon of frozen rocks increased by 2-4 degrees. In the following 20 years the temperature increase accelerated, and in the next 20-30 years the permafrost area may decrease by $10-18 \%$, and by the middle of the $21^{\text {st }}$ century it can decrease by $15-30 \%$. Its border in the Russian Federation will shift to the northeast by $150-200 \mathrm{~km}$. Thawing of frozen soils leads to a decrease in the bearing capacity of foundations, subsidence of the earth's surface, development of thermokarst and thermoerosion, leading to damage of infrastructure. It is estimated that in the coming decades, the most serious consequences of thawing permafrost will be observed at the southern border of permafrost, in particular, in the area of the Baikal-Amur Mainline (BAM) (Figure 2) (Second Assessment..., 2014).

This will lead not only to an increase in the rate of degradation of permafrost, but also to the emergence of new degradation sites and associated deformations. In addition, climate change contributes to 
the intensification of mudflows, avalanches, landslide processes at infrastructure sites in the mountainous areas, as well as to the effects of streambed processes and floods on large watercourses, which are crossed by the railways. In most cases, the sources of destructive impacts can be found on the territory adjacent to the railway. Therefore, pre-design surveys should include a rational choice of engineering protection methods during the modernization or construction phases of the railway infrastructure.

Permafrost thawing may affect several railway lines in Norway and Sweden as shown in Figure 3, a dozen of lines in Canada and Alaska (USA) (Figure 4), as well as in Highland China. The QinghaiTibet railway in China is a unique line $1,956 \mathrm{~km}$ long, a half of which passes at altitudes of 4,000-5,000 $\mathrm{m}$ abs, from which $552 \mathrm{~km}$ on permafrost. The line includes the Tanggula Pass at 5,072 $\mathrm{m}$ which is the world's highest point on a railway, and Tanggula railway station at 5,068 $\mathrm{m}$, the world's highest railway station. In the summer, the upper layer thaws, and the ground becomes muddy. For areas with fragile permafrost, an embankment of large rocks was built. In the areas of fragile permafrost, the rail bed was elevated like a bridge. Similar to the Trans-Alaska Pipeline System (TAPS), which is a 1,287 km long trans-Alaska crude oil pipeline, parts of the rail tracks in Tibet are also passively cooled with ammoniabased heat exchangers (World experience..., 2017).

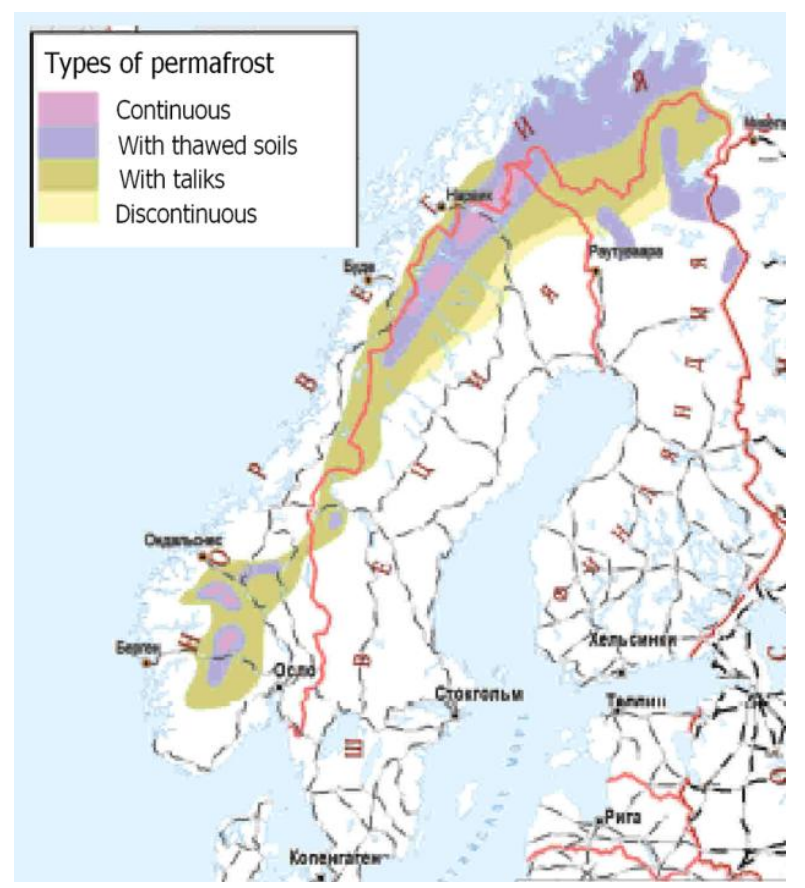

Figure 3. Map of railways in Scandinavia and the areas of permafrost. Adapted from (World experience..., 2017)

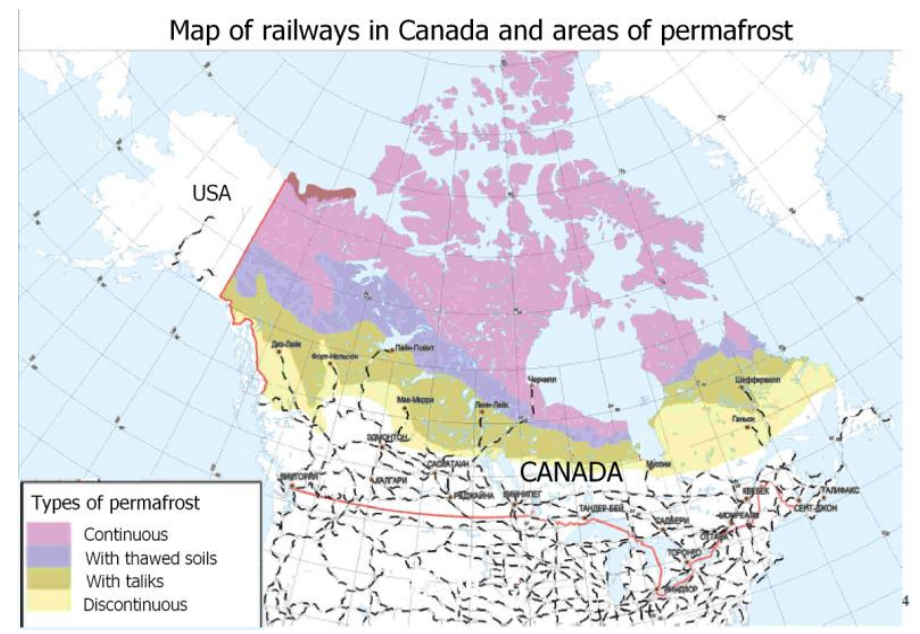

Figure 4. Map of railways in Canada and the areas of permafrost. Adapted from (World experience..., 2017) 


\section{Strong winds}

Strong winds can cause loss of contact of the current collector with the contact wire, increase the risk of derailment or tipping of the train. This has been the subject of research for high-speed trains in many countries, for example, X2000 trains in Sweden (Andersson et al., 2004), ICE in Germany (Diedrichs et al., 2007) and Class 390 Pendolino in the UK (Baker et al., 2004). For example, a study in Austria showed that wind with a speed of over $120 \mathrm{~km} / \mathrm{h}$ can, under certain conditions, overturn a train or cause serious damage. Wind speed of more than $130 \mathrm{~km} / \mathrm{h}$ can cause vibration of the contact wire, which can increase the risk of serious problems with the current collector. In addition, a strong wind can also move parked freight wagons and shift cars inside freight wagons (Rachoy \& Spazierer, 2008). Strong winds can also lead to accidents and railway network disturbances due to collision of the trains with fallen trees, branches or construction debris deposited on the rails (Baker et al., 2009). Such high wind speeds now occur more often in Europe. For example, on January 18, 2007, a windstorm swept across Europe, reaching the maximum wind speed of $216 \mathrm{~km} / \mathrm{h}$, in Germany $-148 \mathrm{~km} / \mathrm{h}$, and in Austria $-140 \mathrm{~km} / \mathrm{h}$. Recently, on 18 January 2018 storm Friederike crossed northern Europe with strongest winds (up to 203 $\mathrm{km} / \mathrm{h}$ recorded in Brocken, Germany). Deutsche Bahn cancelled all long distance services and hired an additional 150 foresters because of the damage to the railways caused by fallen trees. A total damage was estimated from 1 to 2.6 bln Euro. On 23 September - 4 October 2019 storm Lorenzo affected United Kingdom, Ireland, and France with the highest wind gust of $163 \mathrm{~km} / \mathrm{h}$ and damage estimated at 284-330 mln Euro. On 7-16 February 2020 storm Clara affected United Kingdom, Ireland, Isle of Man, Northern Europe, Western Europe, Central Europe, and Eastern Europe with the highest wind gust of $219 \mathrm{~km} / \mathrm{h}$ and damage estimated at 1.6 to 1.9 bln Euro. On 13-19 February 2020 storm Dennis affected United Kingdom, Republic of Ireland, Iceland, Norway, Sweden, and Netherlands with the highest wind gust of $230 \mathrm{~km} / \mathrm{h}$ (List of European windstorms, 2020).

\section{Floods}

Flooding is another serious problem for the railway infrastructure and a subject for many research and assessment projects. For example, a study by Kafalenos and Leonard (2008) on the effects of climate change on US transport in the northern Gulf of Mexico showed that 30 to $40 \%$ of the region's railways will be affected by waves from 5.5 to 7 meters high due to the predicted increase in intensity and the number of hurricanes associated with climate change. In the UK, projected more frequent warm and humid winter periods are estimated to lead to flooding of railway sections, an increase in the impacts on drainage systems, damage to earthworks and cause track circuit problems. In contrast, the associated decrease in snow- and ice-related and low-temperature incidents is deemed beneficial (Baker et al., 2009).

An example of extreme weather events, which resulted in considerable damage for the UK coastline and railway infrastructure, is winter storms and flooding which occurred between December 2013 and January 2014. It was the wettest December since records started in 1910 for Scotland; January was the wettest for southern England since 1910 (Met Office, 2014a, Met Office, 2014b). The storms resulted in breaching the sea wall in several places along a coastal railway stretch of the London to Penzance line at Dawlish, in Devon, which left the railway tracks unsupported. The railway remained closed for two months, which is the longest period it had ever been closed, since its opening in May 1846. It has often been subject to closure due to storm events and high seas (Dawson et al., 2016).

Heavy rains have become a serious problem for railways infrastructure in the Black Sea coastal zone of the Krasnodar Territory of the Russian Federation. They lead to a significant increase in water levels in rivers, flooding of villages, roads and railways, as well as to landslides (Figs. 5-7). Such heavy rains occurred on 8 August 2002 in the area of the city of Novorossiysk; on 6-7 July 2012 five-month precipitation $(275 \mathrm{~mm})$ fell overnight in the area of Krymsk, Novorossiysk and Gelendzhik; on 7-8 September 2018 heavy rains hit the entire coastal zone from Adler to the Kerch Strait; on 23-25 October 2018 heavy rains destroyed roads and railways and bridges in the Tuapse region (Figs. 5-7); on 24 June 2019 heavy rains caused landslides and damaged roads and tourist infrastructure in the mountain resort region of Krasnaya Polyana near Adler; on 29 June, 16 and 25 July 2019 heavy rains again hit and flooded the city of Sochi; on 17 August 2019 Sochi and Lazarevskoe were flooded by heavy rains; on 6 September 2019 Khosta region of Sochi was flooded and landslides damaged roads; on 17 September 2019 again heavy rain hit Sochi, Khosta and Adler (Kostianoy et al., 2019). Russian railway infrastructure is often impacted by floods in Primorye, Amur Region, Khabarobsk Krai, and Sakhalin in the Far-East of Russia. Intense atmospheric cyclones bring heavy rains and strong wind in these regions. 


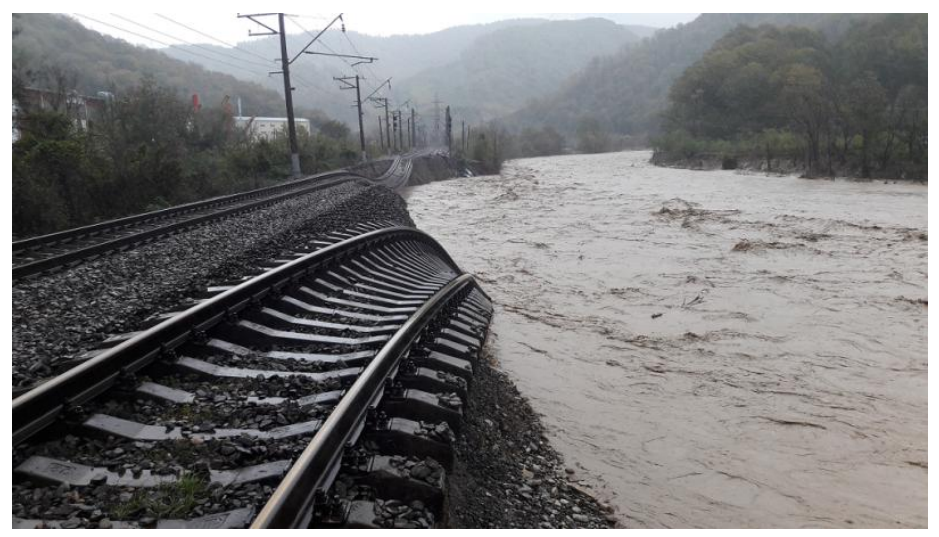

Figure 5. A crash of railway tracks in Tuapse Region due to heavy rains and mud floods along the Tuapsinka River in October 2018 (Source: Russian Railways)

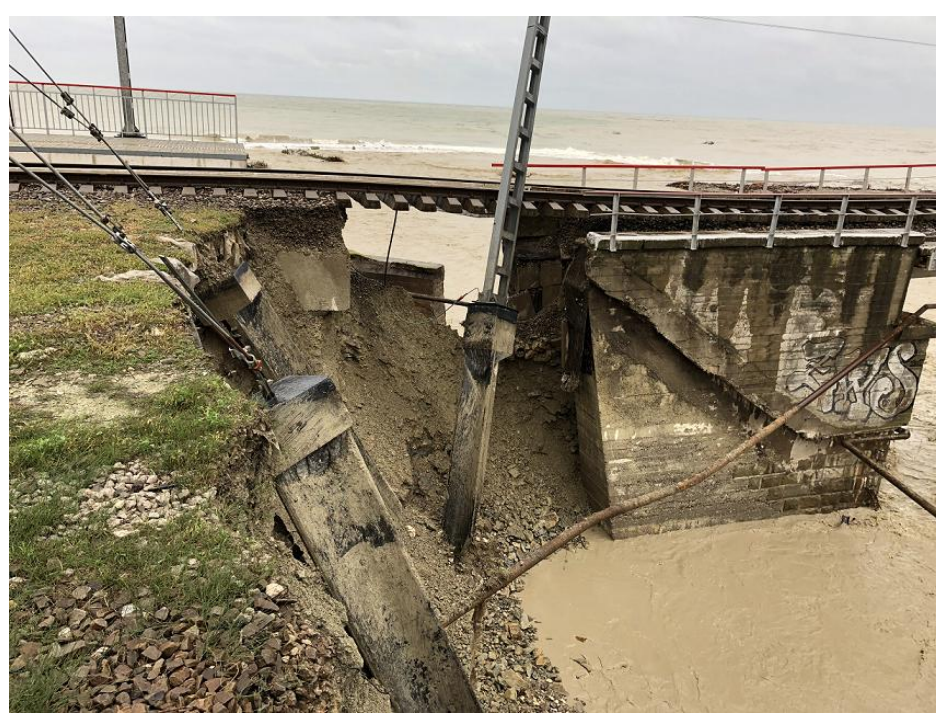

Figure 6. Scour of the bridge over the Makopse River in Tuapse Region due to heavy rains on October 24-25, 2018, which caused mud floods (Source: Russian Railways)

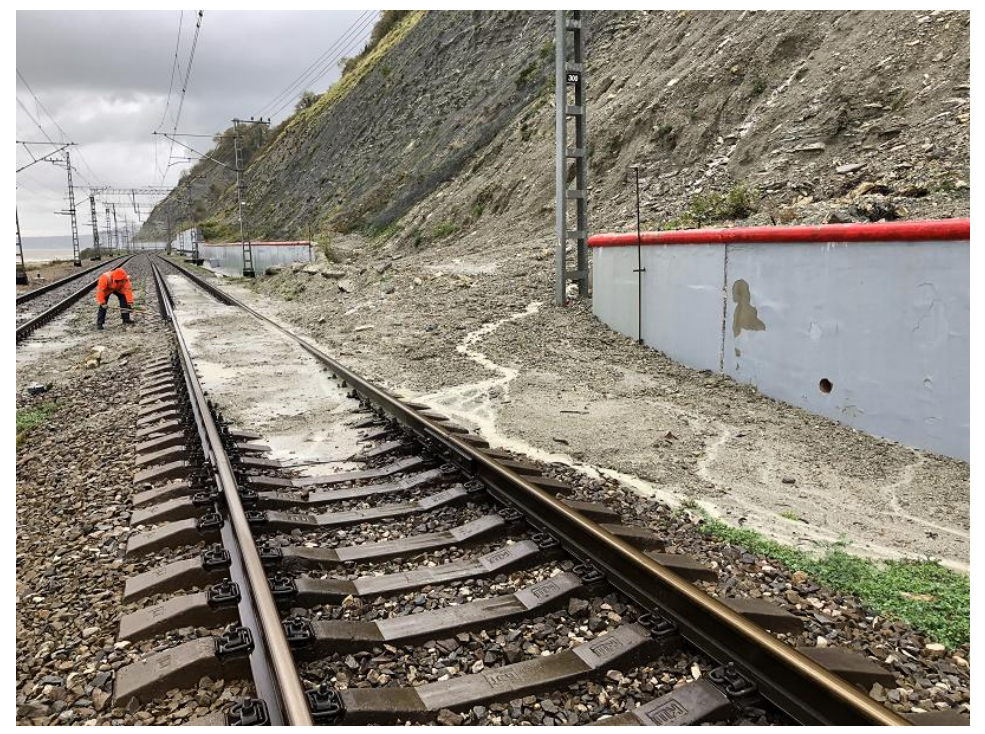

Figure 7. Landslide on the railway tracks in Tuapse Region due to heavy rains in October 2018 (Source: Russian Railways) 


\section{Sea level rise}

Sea level rise even by $30-40 \mathrm{~cm}$ in the coming decades can have serious consequences, both for sections of the railway running along the coastline and for railways in cities located at river mouths. In this regard, there is a need to build additional protective infrastructure on the coast (Baker et al., 2009). Dawson et al. (2016) have shown that days with line restrictions seem to be projected to increase by up to $1170 \%$, to about $84-120$ per year, by the year 2100 in a high sea-level rise scenario $(0.55-0.81 \mathrm{~m})$, for the Dawlish to Teignmouth stretch of the London to Penzance railway line, in the UK. A report by Railway Safety and Standards Board (2008) investigated the susceptibility of the Great Western Main line at Dawlish under various climate scenarios. Interestingly, it showed that the impact of increasing sea level rise was more significant than the impact of increasing wave heights.

In the Russian Federation, there are three coastal sections of the country's railways that require thorough monitoring due to the sea level rise or flooding incidents. These are railway stretches in Sakhalin Island, in the area between cities of Tuapse and Adler in Krasnodar region on the Black Sea, and in Kaliningrad region on the Baltic Sea. In Sakhalin Island, railways stretch northward from YuzhnoSakhalinsk City along the western (the Sea of Japan) and eastern (the Sea of Okhotsk) coasts of the island in the immediate proximity of the shoreline (Figure 8). On the Black Sea, the line between Tuapse and Adler in Russia, and further south to Sukhum in Abkhazia goes also along the shore, and in many places along the beaches of the resort areas (Figure 9). Storms with high waves lead to coastal erosion and impact these sections of the railways, and with the sea level rise this problem will rise significantly.

In Kaliningrad region, there are no railways running along the coast, however, a similar problem may arise in the coming decades due to the sea level rise and lowering of the earth's crust in this area. This can cause accelerated flooding of the lowlands of Kaliningrad region, which will lead to a significant expansion of the river streambeds of the Pregolya and Deyma rivers. Such extension can actually turn Sambia Peninsula into an island, separating it from the mainland in the area of Gvardeisk town. This will require construction of a number of new bridges and the transfer of part of the railway tracks. In this regard, it is extremely important to conduct studies on the sea level rise for the Baltic, Black, Japan and Okhotsk Seas, as well as wave regime and coastal erosion in the areas adjacent to the indicated sections of the railway network.

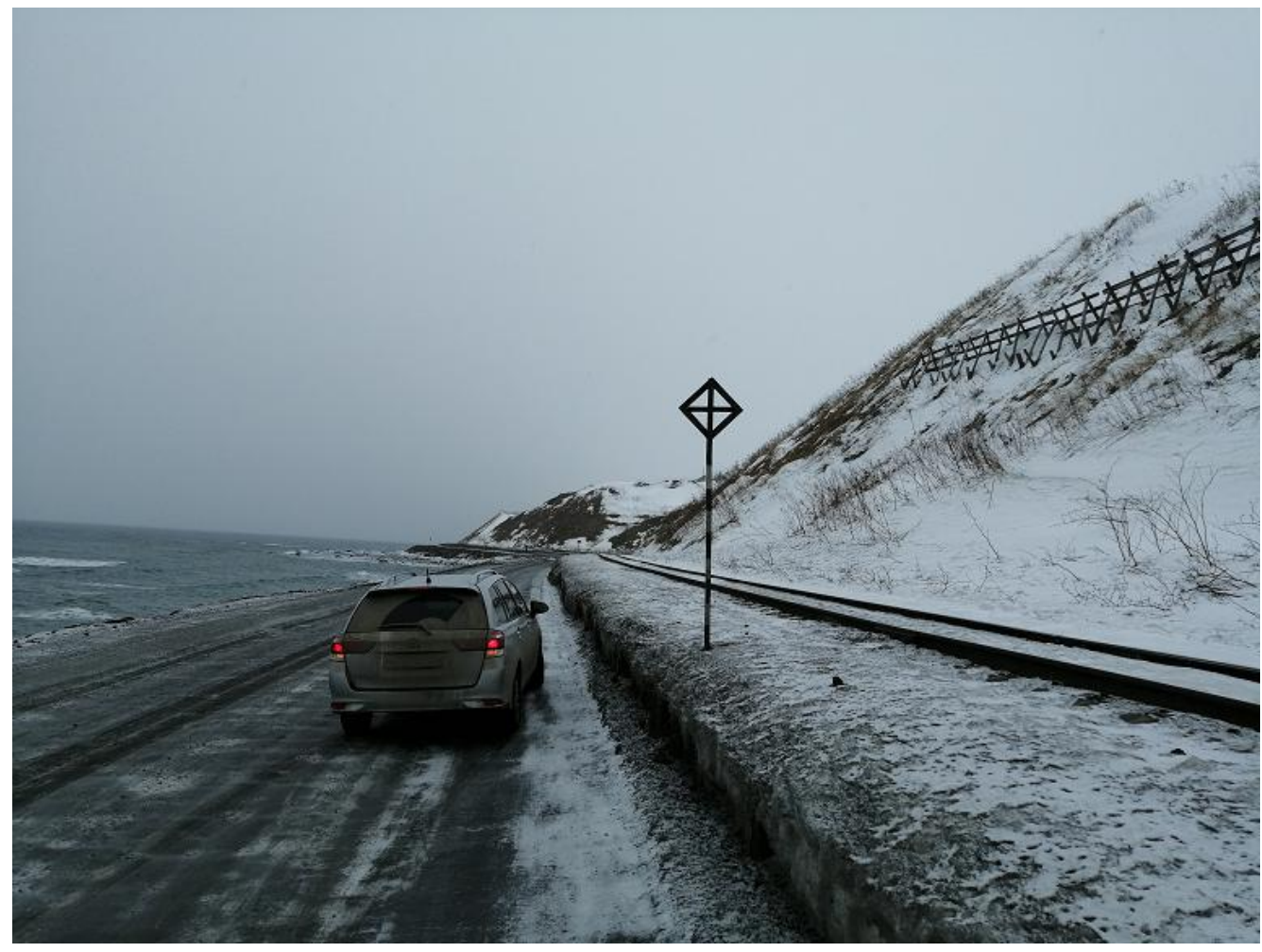

Figure 8. Railway line along the western coast of Sakhalin Island (Photo by Mikhail A. Scheglov) 


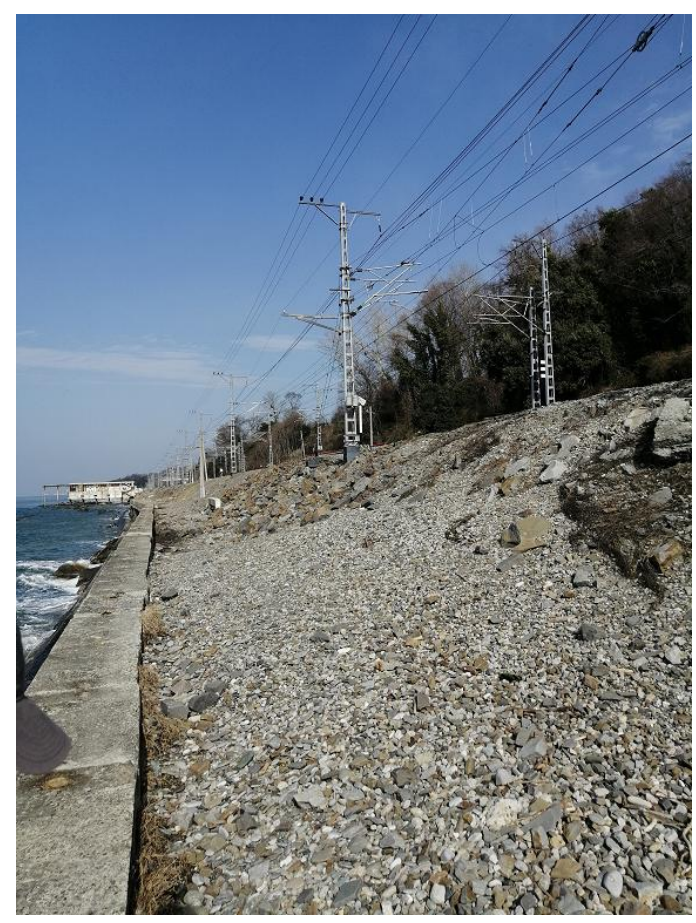

Figure 9. Railway line along the Black Sea coast between Tuapse and Adler (Photo by Mikhail A. Scheglov)

\section{Long-term effects}

Climate change may also have an indirect impact on railway transport. Climate change impacts can lead to additional financial costs caused by train delays, changing or canceling routes. In the long term, a change in commercial flows on the railway may occur due to the impact of climate change on the economic relations and logistics between production areas and product consumption areas. In addition, climate change can directly or indirectly affect the change in the total cost of freight transportation, due, for example, to delays and interruptions associated with extreme weather events (Koetse \& Rietveld, 2009). For example, since 2019, in the Russian Federation there have been negotiations between Russian Railways, Russian Federal Agency for Fishery (Rosrybolovstvo), State Atomic Energy Corporation Rosatom, and Russian Ministry of Transport on the use of the Northern Sea Route as a partial alternative to railways transportation of fishery products from the Russian ports on the Pacific Ocean to the European part of Russia. This became possible due to significant sea ice extent decline in the Russian Arctic Seas.

\section{Adaptation}

Research on the impact of climate change on railway transport also involves studying of possible adaptation mechanisms. Various countries are considering different adaptation measures depending on the specific climate change impacts on their railway system. Researchers from Sweden consider it appropriate to start by examining the range of adaptation to existing challenges, the impact of which may increase with climate change (Lindgren et al., 2009).

Nemry and Demirel (2012) in their report "Impacts of Climate Change on Transport: A focus on road and rail transport infrastructures" laid out current practices used to reduce certain climate change effects on railway infrastructure. Measures to prevent rail buckling derailment include improvements in weather forecast and predictive capacity for rail track temperature; keeping stress free temperature to the initial level, and implementing speed limits in case of high temperature. Some specific adaptation efforts encompass:

1) Improving prediction and monitoring of track temperature conditions;

2) Use of new materials features (for example, sleepers) and setting techniques (for example, fasteners);

3) Upgraded maintenance practices to keep the stress free temperature, as well as inter-seasonal repairing track and ballast resurfacing. It is also advisable to adapt such maintenance periods 
to local weather conditions, so that specific climate in different regions of a country can be taken into account;

4) Amending stress free temperature to accommodate new conditions, which needs to be confirmed in reality.

Overall, further risk of track buckling depends on such factors as interseasonal climate variability, summer temperature, maintenance procedures, and capacity for weather forecast.

Another considerable problem for railway infrastructure is bridge scour, which can be caused by increased precipitation, storm surges or sea level rise in the long term. The most common adaptation measures include riprap and reinforcing the bridge foundation with concrete. Riprap involves placing large blocks at the foot of the bridge piers in order to protect the foundation footings and piers from the impact of flooding. However, if the water velocity exceeds $12 \mathrm{~km} / \mathrm{h}$ for sandy grounds and $10 \mathrm{~km} / \mathrm{h}$ for non-sandy material, riprap starts to be ineffective and foundations have to be strengthened, which suggests additional concrete around foundation (Nemry and Demirel, 2012).

"Rail Adapt: Adapting the railway for the future" (UIC, 2017) is another extensive report specifically on adaptation of railways, which was prepared by the International Union of Railways. It lays out four aspects of organizational development that a railway requires in order to efficiently adjust to climate change: organizational capacity, assessment of existing capacity, building capacity, and communication of adaptation. Organizational capacity involves ability of a railway organization to respond to various existing and emerging issues, which means the capability to understand, plan, implement, monitor, assess, review and learn from such issues. Assessment of existing capacity would be the first step in building organizational capacity. Actions for building capacity may include sourcing climate information; reviews of organizational policies and aims, changing asset management strategies in order to permit adaptive design and maintenance measures; amending technical standards, adopting necessary design and maintenance parameters; training or retraining of staff; arranging briefing sessions relevant for organizational needs. Communication is essential for a railway company at various levels: from freight users and passengers to local stakeholder groups and companies globally.

Canada's considerations on adaptation correspond to the adaptation rationale above. Specifically, Canada views potential adaptation mechanisms in the following five directions:

1) Organizational planning, policies and designs;

2) Undertaking risk and vulnerability assessments;

3) Implementing structural and physical (engineering) adaptations;

4) Integrating smart technologies;

5) Changing operations and maintenance practices.

Measures taken under each of these directions are manifold. For example, the British Columbia Ministry of Transportation and Infrastructure requires infrastructure design work to take into account climate change adaptation. Transportation practitioners test and implement engineering techniques, for example thermosyphons, in order to reduce permafrost thaw under infrastructure. They also use fiber optic technologies for monitoring of permafrost degradation. GO Train engineers raise preferred raillaying and rail-distressing temperatures for track, for reducing buckling risks to rail lines from high temperatures. Railway companies perform vulnerability assessments and GIS mapping of the territories at risk from washouts, landslides, and other natural hazards. Wind sensors are installed on some rail bridges, which allows rail operators to adjust speed or delay passage. Overall, railway companies actively monitor climate risks, weather events, by installing washout detectors and laser movement detection systems. They also use fiber optics to detect slope movements, measure track stability with radar interferometer, and place warning systems for extreme weather (Palko \& Lemmen, 2017).

The Austrian Federal Railways put into action a meteorological information and warning system. Its aim is to ensure timely and reliable provision of necessary information to those responsible for the safe functioning of railways. The system has three main levels of weather forecasting. The first level is a map of Austrian railways with a forecast of the most important weather parameters for 3 days with a resolution of $10 \mathrm{~km}$. Forecast for snowfall is provided six hours in advance, which is extremely important for preparing the necessary operations for snow clearance. The second level involves manual forecasts for wind speed and snowfall in case of higher wind speeds and higher amount of snowfall. The third level is a warning service in case of severe weather, for example, heavy snowfall, winter gale and thunderstorms. Nowcasting techniques (such data as weather radar data, weather station data, and model data) are used to forecast thunderstorms up to 20-60 minutes in advance. This can help take preventive measures such as train speed reductions in order to protect people and equipment. In addition to this information system, a special warning system has been created for forecasted storms, floods, and snowfalls. This is an alert message system that sends out warnings to responsible persons via SMS, e-mail, fax, and telephone. In addition, a meteorologist is on duty 24 hours a day and 7 days a week for consultations in constant communication with railway officials (Rachoy \& Spazierer, 2008). 


\section{Conclusions}

The impact of climate change on railway infrastructure and operations is undeniable. Many countries across the world have already experienced such effects. The human and economic losses can be tremendous. In order to prevent this, it is essential that countries develop adaptation measures in order to prevent infrastructure damage, accidents, delay and cancellation of railway services. Some of such measures require additional research and development of warning systems, performing risk assessments, creating new engineering solutions and technologies, and setting up necessary policies. All of this requires time and investments, and should be planned and performed in due time. Some regions may not have had such devastating climate change impacts on railway infrastructure and services yet, however, they may be projected to have such effects in the near future or in 20,30, or 50 years. Therefore, already at this moment, any new engineering, construction and railway development projects need to take into account international experience and expertise. The authors of this article therefore have come up with the following recommendations for the Russian Federation.

First, there is a need for a comprehensive study on the impacts of regional climate change on infrastructure and sustainable functioning of railway transport in the Russian Federation. Such a study shall result in an extensive report, which should contain specific climate change impacts on the railway system in all of the regions of the country. As these regions vary in terms of climate, climate change speed, rail traffic intensity, economic capabilities for adaptation measures, such a detailed region-specific analysis is absolutely essential for an adequate preparation for the future climate change scenarios. Such a report should comprise analysis of specific nature hazards for each region, both for the present time and taking into account mid-term and long-term climate change scenarios, and their consequences. In addition, such analysis should include examination and proposal of the adaptation measures for each specific hazard and each region, and the approximate costs for such actions.

The results will be vital to ensure uninterrupted transportation and traffic safety and optimize costs. The results of such study will be especially in demand for choosing engineering solutions to ensure the stability of the track and other infrastructure facilities when reconstructing existing or building new sections of the railway network, primarily in areas where permafrost thawing processes occur under the influence of climate change.

Second, it seems reasonable that, for such comprehensive research suggested above, there is a need for collaborative action among professionals from various fields, including but not limited to: climate change specialists, railway officials and engineers, representatives of the transportation authorities from the regions, economists. It is essential to conduct integral studies and develop a holistic approach to this problem. It is not enough to develop smart systems and technologies alone aimed at identifying impacts of weather on railways. In contrast, it is fundamental to study the effects of long-term climate change or the risks of an increase in the frequency of various extreme weather events in application to the railway network.

Third, special attention should be paid to the assessment of the projections for flooding and sea level rise for the following regions: Kaliningrad Region, area between Tuapse and Adler, and Sakhalin Island. Here, assessments should be made of the current situation and projected changes with consideration to move the railway further from the coast to avoid damage to infrastructure, threat to human lives, and prevent overall socio-economical losses.

\section{Acknowledgements}

Andrey G. Kostianoy was partially supported in the framework of the P.P. Shirshov Institute of Oceanology RAS budgetary financing (Project N 149-2019-0004).

\section{References}

1. Andersson, E., Häggström, J., Sima, M., and Stichel, S. (2004) Assessment of train-overturning risk due to strong cross-winds. Proc. IMechE, Part F: J. Rail and Rapid Transit, 218(3):213-223. DOI: $10.1243 / 0954409042389382$.

2. Atlas of natural and technological hazards and risks of emergency situations. Russian Federation. (Ed. S.K. Shoigu) (2010) EMERCOM of Russia, Moscow, 696 pp.

3. Baker, C.J., Chapman, L., Quinn, A. and Dobney, K. (2009) Climate change and the railway industry: a review [online]. Available from: http://journals.sagepub.com/doi/pdf/10.1243/09544062JMES1558 [Accessed 20 September 2017]. 
4. Baker, C.J., Lopez-Calleja, F., Jones, J., and Munday, J. (2004) Measurements of the cross wind forces on trains. J. Wind Eng. Ind. Aerodyn., 92:547-563.

5. Dawson, D., Shaw, J., \& Gehrels, W. R. (2016) Sea-level rise impacts on transport infrastructure: The notorious case of the coastal railway line at Dawlish, England. Journal of Transport Geography, 51, 97-109.

6. Diedrichs, B., Sima, M., Orellano, A., and Tengstrand, H. (2007) Crosswind stability of a highspeed train on a high embankment. Proc. IMechE, Part F: J. Rail and Rapid Transit, 221(2):205225. DOI: $10.1243 / 0954409 J R R T 126$.

7. DMF (2015) Holding the line? Reviewing the impacts, responses and resilience of people and places in Devon to the winter storms of 2013/2014. A Summary Report from the Devon Maritime Forum.

8. Dobney, K., Baker, C.J., Quinn, A.D. and Chapman, L. (2009) Quantifying the effects of high summer temperatures due to climate change on buckling and rail related delays in south-east United Kingdom [online]. Available from: http://onlinelibrary.wiley.com/doi/10.1002/met.114/pdf [Accessed 20 September 2017].

9. Ferranti, E., Chapman, L., Lee, S., Jaroszweski, D., Lowe, C., McCulloch, S., \& Quinn, A. (2018) The hottest $\mathrm{J}$ uly day on the railway network: insights and thoughts for the future. Meteorological Applications, 25(2), 195-208.

10. Grigoriev, A.V., and Lepov, V.V. (2012) Mechanisms for the accumulation of damage and destruction of the material of the rim of a railway wheel during operation in the North. Bulletin of the North-Eastern Federal University, 9(1):79-85 (in Russian).

11. Grigoriev, A.V., and Lepov, V.V. (2014) The influence of low climatic temperatures on the resource of the material of railway wheels. Fundamental Research, Engineering Scinces, 5:18-22 (in Russian).

12. HoCTC (2015) House of Commons Transport Committee Investing in the railway. Seventh Report of Session 2014-15. Published on 23 January 2015 by authority of the House of Commons London.

13. IPCC (2014) Climate Change 2014: Synthesis Report. Contribution of Working Groups I, II and III to the Fifth Assessment Report of the Intergovernmental Panel on Climate Change [Core Writing Team, R.K. Pachauri and L.A. Meyer (eds.)]. IPCC, Geneva, Switzerland, 151 pp.

14. Kafalenos, R.S., and Leonard, K.J. (2008) What are the Implications of Climate Change and Variability for Gulf Coast Transportation? In: Savonis, M.J., Burkett, V.R., Potter, J.R. (Eds.), Impacts of Climate Change and Variability on Transportation Systems and Infrastructure: Gulf Coast Study, Phase I, Report by the U.S. Climate Change Science Program and the Subcommittee on Global Change Research, Department of Transportation, Washington, DC, USA.

15. Koetse, M.J., and Rietveld, P. (2009) The Impact of Climate Change and Weather on Transport: An Overview of Empirical Findings. Available at:

http://www.webmeets.com/files/papers/EAERE/2009/1020/EAERE2009\%20paper\%20Koetse.pdf [Accessed 20 September 2017].

16. Kostianoy A.G., Lebedev S.A., Soloviev D.M., Tepe Y. (2019) On river plumes along the Turkish coast of the Black Sea. Ecologica Montenegrina, 25, 63-78.

17. Li, D., \& Kaewunruen, S. (2019) Effect of extreme climate on topology of railway prestressed concrete sleepers. Climate, 7(1), 17.

18. Lindgren, J., Jonsson, D.K., and Carlsson-Kanyama, A. (2009) Climate Adaptation of Railways: Lessons from Sweden [online]. Available at: http://www.ejtir.tudelft.nl/issues/2009_02/pdf/2009_02_05.pdf [Accessed 20 September 2017].

19. List of European windstorms (2020) Available at: https://en.wikipedia.org/wiki/List_of_European_windstorms [Accessed 28 May 2020].

20. Mandal N.K., Lees M. (2016) An investigation into monitoring rail stress in continuously welded rails through stress-free temperature. Proc. Conference on railway engineering, Melbourne Australia.

21. Met Office (2014a) Winter storms, December 2013 to January 2014 [online]. Available at: https://www.metoffice.gov.uk/binaries/content/assets/metofficegovuk/pdf/weather/learn-about/ukpast-events/interesting/2013/winter-storms-december-2013-to-january-2014---met-office.pdf [Accessed 10 May 2020].

22. Met Office (2014b) The Recent Storms and Floods in the UK [online]. Available at: https://www.ceh.ac.uk/sites/default/files/Recent\%20Storms\%20Briefing.pdf [Accessed 10 May 2020].

23. Nemry, F. and Demirel, H. (2012) Impacts of Climate Change on Transport: A focus on road and rail transport infrastructures [online]. Available at: http://ftp.jrc.es/EURdoc/JRC72217.pdf [Accessed 20 September 2017]. 
24. Oslakovic, I.S., ter Maat, H.W., Hartmann, A. and Dewulf, G. (2013) Risk assessment of climate change impacts on railway infrastructure [online]. Available at:

https://core.ac.uk/download/pdf/29215286.pdf [Accessed 08 May 2020].

25. Palco, K., and Lemmen, D.S. (Eds.). (2017) Climate Risks and Adaptation Practices for the Canadian Transportation Sector. Ottawa, ON: Government of Canada. Available at: http://www.nrcan.gc.ca/environment/impacts-adaptation10761 [Accessed 20 September 2017].

26. Rachoy, C., and Spazierer, M. (2008) Meteorological information and warning system for railway infrastructure decision support for natural hazards management. In: Proceedings of the World Congress on Rail Research, Seoul, Korea, Paper I.3.1.1.3. Available at: http://www.railwayresearch.org/IMG/pdf/i.3.1.1.3.pdf [Accessed 20 September 2017].

27. Rail Safety and Standards Board (2003) Safety implications of weather, climate and climate change. Report prepared by AEA Technology.

28. Rail Safety and Standards Board (2016) Tomorrow's Railway and Climate Change Adaptation: Executive Report. Available at: www.rssb.co.uk [Accessed 20 September 2017].

29. Rail Safety and Standards Board (2008) Impact of climate change on transport infrastructure. Report prepared by Mouchel Parkman.

30. Russian Ministry of Railways (2000) Engineering instructions for the installation, laying, maintenance and repair of the continuous welded rail. Moscow, "Transport", 96 p. (in Russian).

31. Russian Railways (2012) Instruction for the installation, laying, maintenance and repair of the continuous welded rail. Moscow, Russian Railways, 137 p. (in Russian).

32. Second Assessment Report of Roshydromet on Climate Change and its Concequences on the Territory of the Russian Federation. (Eds.) V.M. Kattsov and S.M. Semenov, Moscow, "Planeta", 2014, 1018 p. (in Russian).

33. UIC (2017) Rail Adapt: Adapting the railway for the future. Available at: https://uic.org/IMG/pdf/railadapt_final_report.pdf [Accessed 08 May 2020].

34. World experience on construction, maintenance and repair of objects of railway infrastructure under conditions of permafrost soil. Center for Scientific-Technical Information and Libraries, Russian Railways, 2017, 126 pp. (in Russian). 